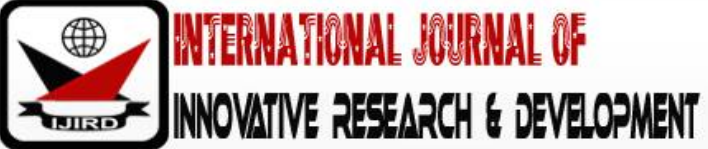

ISSN 2278-0211 (Online)

\section{Re- assessing the Root Causes of Conflict in the Horn: The Case of Oromia and Somali Regional States in Ethiopia (1991- 2018)}

\author{
Dr. Temesgen Bayissa Gelle \\ Lecturer, Department of Law and Governance, \\ Oromia State University (OSU), Ethiopia
}

\begin{abstract}
:
This article intended to re-assess the root causes of conflict along the common borders of Oromia and Somali regional states in Ethiopia based on personal interviews, group discussions and secondary data that was held in Mi'esso (Oromia) and Mi'esso (Somali) and Moyale (Oromia) and Moyale (Somali) districts. Accordingly, the root causes of the post 1991 ethnic conflicts in Ethiopia, mainly along the common boundaries of both regional states was multiple and complex. These causes are associated with nation building processes and power sharing conflicts. The theoretical ground of this study claims that the conflict in both regions was a clash between conflict actors over scarce resources which finally transferred to administrative border contestation. In addition to this, the idea of Greater Somalia was a historical factor that the legacies of the 1960s and 70s Somali politics in the Horn of Africa still has got impacts in the local level conflict between the Oromo and Somali. The main actors of the conflict in both regions includes the local administrative, militia, demobilized soldiers, Fetno-Derash of Oromia and the Liyu police of Somali and the paramilitary forces. The forces have been fighting under the guise of local people, which has been strictly concealed at the administrative levels. In general, the Oromo-Somali border conflicts have been built over a long period of time and brought about numerous economic, political and social (humanitarian) crisis. The conflict has frequently left hundreds of thousands displaced people, and many more death and injury. Data from the Displacement Tracking Matrix (DTM) indicate at least 1,073,764 People were displaced by conflict in 2018 and live in government collective centers.
\end{abstract}

Keywords: Conflict, ethnic conflict, regional states, federalism

\section{Introduction}

\subsection{Background}

Violent conflict is the norm in the Horn of Africa. Conflicts are waged at various levels: state, regional, and local. Conflict in the Horn of Africa involves various actors: governments, nationalist groups, religious groups, and community or identity groups with significant backing from external forces. It is a common for conflicts in the sub-region to promptly acquire a sub-regional dimension, thus transcending national borders by attracting kinsmen from across the border in the Horn of Africa (Tadase and Yohanes, 2016).

Ethiopia is located in the Horn of Africa and bordered by Eritrea, Djibouti, Somalia, Kenya, Sudan and South Sudan. Following the political transition of 1991, Ethiopia introduced the Constitution of the Federal Democratic Republic of Ethiopia (FDRE) that resulted in the creation of nine regional states and two city administrations. The Oromia and Somali regional states are among the nine bordering states.

Oromia National Regional State with its capital Finfinnee/Addis Ababa is the largest state in the Ethiopian Federation. The total area of the region is 363,136 square kilometers, accounting for about $34.3 \%$ of the total area of the country. The total size of the population of the region is $27,158,471$ and covers $36.7 \%$ of the total population of the country (CSA, 2007). Administratively, the region is divided into 20 administrative zones, 365woredas/ districts (out of which 39 are towns structured with the level of woredas and 265 rural woredas), and more than 6,342 farmers and 482 urban dwellers Kebeles. The Oromia State shares border with all the regional states in the Federal Democratic Republic of Ethiopia, except Tigray. It also shares international boundaries with the South Sudan in the west and Kenya in the south. Oromia is located between 3- and 15-degrees' north latitude, and 33- and 40-degrees' east latitude. (BoFED, 2008).

The Somali National Regional State (SNRS) is in the eastern-most corner of Ethiopia, and shares borders with Kenya, Somalia, the Republic of Djibouti, and the Afar and Oromia Regional States to the west. Its capital Jig-jiga is located in the eastern and south-eastern part of Ethiopia. The Ethiopian Somali region covers an area of 279,252 square kilometers. The total size of the population of the region is 4,439,147 and covers $6.0 \%$ of the total population of the country (CSA, 2007). Administratively, the region is divided into 11 zonal administrations and 93(Abdusalam,2018:41) Districts. The State has common boundaries with Afar and the Republic of Djibouti in the north, Kenya in the south, the State of Oromia in the west, and Somalia in the east and in the south. 
Oromia and Somali regional states share more than 1552 kilometers long borders mostly, not clearly demarcated. The Oromo-Somali conflict which manifested violently for many years. The pattern of conflict is complex with several factors contributing to the perpetuation of conflicts. Conflicts started in certain areas easily expand to other areas sharing borders. The conflicts with the involvement of pastoralist communities attract the involvement of the two states revealing the economic, political, ethnic, religious and regional dimensions of the conflicts (Asnake, 2004). Thus, the socio-economic and political dynamics related with formation of regional states provides additional incentives for the protracted conflicts and revolve around administrative borders and scarcity of resources (mainly water, grazing land) has increased hostilities and violence between pastoralists and agro-pastoralists which has been compounded by an influx of refugees.

\subsection{Objectives and Methodology of the study}

This Article assesses the conflict dynamics between the common borders of Oromia and Ethiopian Somali regional state of Ethiopia. More specifically, it aims at investigating the major causes and the actors of conflict along the common borders of Oromia and Somali Regional States from 1991-2018.

This study employed a qualitative approach and case study method. Data were obtained through Interviews and FGD from community elders and local administrative officials in Oroma and Somali regions in 2015 and 2016 respectively. In addition, significant literature review on the conflict in the region was made. To explain the conflicts along the common borders of Oromia and Somali NRS, two cases that geographically and politically cover four adjacent "hotspot" districts or flash points in the border areas are selected. Accordingly, Mi'esso (Oromia), and Mi'esso (Somali) districts were selected from the eastern side of both regions, and Moyale (Oromia) and Moyale (Somali) districts from the southern part were selected from both regions. The reasons for the selection of these districts includes but not limited to the fact that they have experienced frequent conflicts and were sites of potential conflicts. They are also strategically important in that Mi'esso is on the railway line that connects Addis Ababa to Djibouti in the eastern side, while Moyale is a gateway to Kenya in the southern extreme. In addition, some web based and media sources have also been used,

\subsection{Concepts of Conflict and Theoretical Framework}

Conflict is an active disagreement between people with opposing opinions or principles. It is present when two or more parties perceive that their interests are incompatible, express hostile attitudes, or take pursue their interests through actions that damage the other parties. These parties may be individuals, small or large groups, and countries. Conflict arises in different contexts, and occurs at the intrapersonal, interpersonal, intergroup, organizational, and international levels. Conflict exists when incompatible goals develop between persons, groups, or nations (Deutsch and Coleman 2000). Interests can diverge in many ways: Over resources (territory, money, energy sources, food and how they should be distributed). Over power (how control and participation in political decision-making are allocated). Over identity (concerning the cultural, social, and political communities to which people feel tied). Over status (where people believe they are treated with respect and dignity and where their traditions and social position are respected). Over values (particularly those embodied in systems of government, religion, or ideology) (Muhabie, 2015:29).

Violent conflict: Conflicts can become violent when parties go beyond seeking to attain their goals peacefully, and try to dominate or destroy the opposing parties' ability to pursue their own interests. With so much violence around the world, we might assume that violent conflict and coercion are the natural order of things: human beings are inherently aggressive, and wars and violent conflicts are inevitable. Yet violence does not always occur, even when interests differ: violence is not inevitable. Violence is contingent upon the presence or absence of certain conditions. Destructive conflicts tend to expand and escalate as competition, poor communication, hostile attitudes, misjudgment, and misperception take hold so that the parties get stuck in a situation that makes no logical sense (Kriesberg 1998).

\subsection{Theory of Causes of Conflict}

A large volume of literature is written about the nature and theory of conflict on one hand, and lack of consensus among both contemporary and long-established views of human conflict on the other made conflict studies uneasy. Concerning this, J.A Schellenberg notes that, there are many versions of conflict theories and many different theories about conflict (Schellenberg, 2005:12). Due to the constraints of time and space, it is difficult to deal with each theory and its approach. Nevertheless, categorizing theories in to the major groups might help one to scrutinize the theories of conflict definitely. There is a marked polarity among theoretical approaches there are two divergent theories: the classical and the behaviorist. The classical theories are primarily concerned with analyzing the interaction of groups. These groups have many categories from national to smallest level group such as ethnicity. The classical theorists attempt to analyze conflict situations from conscious interaction of human being. The units of analysis are may because they perceive conflict from the holistic social perspective.

The behaviorist theories focus on the individual level in which the unit of analysis is the individual rather than the group. This theory gives a special place for the innate traits of individual which instigate him/her toward violent conflict. To behaviorists, the unit analysis is hence the individual. In line with this, there are also many approaches of conflict analysis; however, the majority of them fall under either of the taxonomies discussed above. For further scholarly analysis and discourse of conflict in both the classical theories and behaviorists, I will examine a few but relevant approaches to the study in the subsequent sections under causes of conflict. Currently, it is found to be impossible to list down the causes of conflict and dispute. Pervasiveness of many and varied conflict causes, and complexity to discern actors' interests involved are among others which made causes of conflict the other contentious element among conflict scholars. Thus, different and controversial theories have emerged concerning the causes of conflict (Melaka, 2009). 
Early proponents of behavioral conflict theory just hypothesize that there was an innate instinctual or biological trait that press on human towards violent actions. Freud's 'death instinct' psychological analysis and social Darwinian theories regarding the fight for survival were among others which symbolize this theory (Dejene, 2007.This theory seeks to establish causal relationship between human biological or psychological nature and violent conflict. Many writers share this assertion which associates conflict with the inborn violent behavior of mankind. According to these scholar's human tendency to act aggressively is inborn (Freud, 1961). This theory, however, was subsequently discredited by other writers who made exhaustive ethnographic works particularly in a cephalous society. For example, Robe recheck asserts that, the Semai society, is peaceful and war hating society where warfare is unknown (Robe, 1990). Similarly, Taddesse argues that human behavior is more complex than similar creatures for it can either be peaceful or aggressive across times Taddesse, 1988). Thus, apart from biologist who repudiate the hypothesis of inborn violent human behavior, ethnographic researches have also a paramount contribution to pinpoint its short fall.

Frustration aggression theory, in explaining the causes of conflict assumes that human beings are goal-oriented and rational. Frustration is accumulated when an in individual or a society is blocked from meeting their realization of goal; then it is natural to be aggressive and opt for conflict for the realization and fulfilment of their goals (Jeong, 2000:67). Likewise, Davis's theoretical connection between frustration and aggression seems very explicit among others proponents of this theory. According to Davicies, frustration of subjective (physical, Social- affectional, self- esteem, and selfactualization) or implemental needs (Security, knowledge, and power) turn conflicts in to violent form when certain innate needs or demands are deeply frustrated (Devies, 1973). Be it as it may, now theories of conflict have also emerged while lending analytical tools from Frustration-Aggression theory. In this regard, Human Need Theory remain long cultured theory for analyzing conflict courses, among others. Thus, many and varied approaches of conflict causes were derived from this human need theory. For example, Burton states that, individuals cannot be socialized in to behaviors that destroy their identity and others need goals, and therefore must react against the environment that do this (Burton, 1990). Burton (1990) cited in Jeong (2000:71) further emphasizes that these needs are basic; hence, they are neither negotiable nor traded. The denial and access to these needs makes people to take the option of violence in order to secure their needs. It is the need to reach one's potential in all areas of life (Sandra Marker, 2003). In this context, therefore, the source of conflict is not the behavior of the individual rather the social environment which dictate individuals develop that need. To this perspective, responses of frustration from such a human need will often seem aggressive. In related text, but with a different fashion, Koestler identifies the need for belongingness excessive capacity and urge among humans to become identified with a group, a notion, church, etc. are integrative or self-transcending tendencies which indicate violent conflicts through human history (Koestler, 1972). Moreover, since the demand for basic human needs has always exceeded the supply, all human conflict can be traced to an actor's failure to obtain what it needs. Consistent to this, Thomas Hobbes argues, selfishness of man is the cause of conflict. According to him, human is naturally inefficient to satisfy all of his needs by himself (Hobbes, 1651). Therefore, excessive desire to satisfying these needs will lead human in to conflict. John lock reacted to his logic by attaching the very premises of Hobbes reasoning. John lock maintains that niggardliness of nature (i.e. scarcity) is the cause of conflict among humans (Hobbes, 1951: 43). For lock, nature does not provide us enough resources to satisfy our needs hence it is the cause of conflict (Hobbes, 1951:43). Although the discourses over human need theory having no unitary theoretical analysis regarding causes of conflict, it is better to note that extensions of approaches towards scarcity provide another dimension for conflict studies.

Currently approaches of conflict causes nexus scarcity seems to be the focus of many theories of conflict in which it associated with economic origin of conflict causes. Historically, individuals, social groups and societies have competed over scarce resources such as water, land, and others. However, many scholars are trying to show how scarcity becomes a source of violent conflict once accompanied with other variables such as natural disasters. For scholars like Barth, interethnic and inter-group conflict turns in to violent form once ecological changes take place. This may result stiff competition over resources in which it becomes scarce due to this change (Barth, F 1969:29). This elucidation which tends to construct a causal relationship between ecological factors and conflicts is also shared by other writers. For example, Divale states that, crop failure, draught, natural catastrophe and the consequential competition over resource can lead to conflicts between or among groups (Divale, 1974:56). On the other hand, the relative deprivation theory assumes that conflict erupts when raising expectation and the absence of progress towards better life. In other words, the gap between people's values of expectation and capabilities and the wider gap between their perception and the reality on the ground lead people to make violence and unrest (Jeong, 2000:69). The relative deprivation theory as articulated by Gurr shows that people are bound to rebel when they understand that there is much difference between what by right, they are expected to get and the practical reward. Relative deprivation theory offers an explanation based on an ethnic group's access to power and economic resources (Gurr, 1970). Indeed, most of Horn African conflicts which are reported and which draw inter-state, national and international attention, are those which fit the above description.

\section{Discussions}

\subsection{Back Ground to Oromia-Somali Relations}

The Somali and Oromo languages belong to the eastern Cushitic linguistic group of the Horn of Africa. The two societies are closely related to each other in terms of language and culture. Sociologically, both groups follow the patriarchal clan structures. The Somali practice Islam almost exclusively and are predominantly engaged in nomadic pastoralism. In contrast, the Oromo practice Islam, Christianity and traditional religion. Nevertheless, those Oromo clans 
who reside coterminous with the Somali largely follow the Islamic faith and are predominantly engaged in pastoralism. ${ }^{1}$ Although Islam and pastoralism could be seen as indicators of their commonalities and could serve as instruments of integration, pastoralism, which depends on the mobility of livestock, is often a cause for frequent resource conflicts.

As neighboring ethnic communities, the Somali and the Oromo have longstanding relationships. Both were key players in the 16th century major population movements in the Horn of Africa, which greatly contributed to the present distribution of ethnic groups region (Baxter 1978: 284; Lewis 1966: 27). According to Lewis (1966: 35), interactions between the eastern most Oromo and the western most Somali began during the 1500s and 1600s as the Oromo were expanding to the north, northeast, and southeast. This means the two groups were competing for about 400 years in their borderlands for water, grazing and agricultural lands (Lewis 1966; Turton 1975 cited in Asnake, 2009:181).

Because of their century's old interactions, the Somali and the Oromo have several commonly shared socio-cultural values. For instance, some Oromo and Somali groups have been either Somalised or Oromised. ${ }^{2}$ In this respect, the ethnic identities of Garri and the Gabbra that today compete with the Borana for control of the Moyale town were influenced by years of Oromo-Somali interactions in southern Ethiopia and northern Kenya. ${ }^{3}$ The relationship between the Oromo and the Somali largely remained in the realm of culture and local alliance formation, until it began to change and became politicized because of the partition of the Horn of Africa at the beginning of the 20th century by different powers; state nationalism and ethnic politics. Both have similarities and differences in their relationship with the Ethiopian State. The Somali remained at both the geographic and political periphery for much of the 20th century. The Oromo, in contrast, played key roles in Ethiopian politics at least since the beginning of the 20th century (Clapham 1988: 217; Asnake, 2009:181). The Somali and the Oromia national regional states share more than 1552 kilometers that stretches from Mi'esso district in the east to the Moyale district in the south. As soon as the federal structure was put in place both regional states engaged in protracted claims and counter claims of territories along their indistinct borders. Parallel to the territorial contest, pastoral resource conflicts were rampant in the lowland pastoral Oromo and Somali inhabited areas.

Oromia and Somali Regional states share not only of a border line of more than $1552 \mathrm{kms}$ but also belong to Cushitic languages family. Both regions saw armed insurgent movements in the name of national self-determination during the pre and post-1991. In Oromia the Oromo Liberation Front was established in the 1970s and has been fighting a low-level insurgency since then. The Western Somali Liberation Front (WSLF) started armed opposition to the political center in Somali region during the 1970s with the aim of uniting the Somali inhabited in the part of Ethiopia with the Republic of Somalia. The armed opposition within the Somali areas was strong and was supported by the neighboring irredentist Republic of Somalia. Both regions as compared to the remaining regions of the federation are characterized by political volatility and incidents of conflict. Since the change of the Derg regime in 1991 and the introduction of regional governments, these regions saw several purges with a high level of intervention from the political center. Similarly, geostrategic interests of regional and international players in the Horn of Africa and the continued proxy warfare among the countries of the Horn, Ethiopia and Eritrea in particular, could adversely influence peace and stability in Ethiopia in general and in Oromia and Somali regional states in particular (Abbink 2003).

\section{The Birth of Ethnic Federalism in Ethiopia}

The birth of ethnic federal system is a response of different nationalist movements to the historical trajectory of building a nation-state through ethnic assimilation that gave rise to the 'Nationality Question' in the country. The EPRDF and other nationalist movements introduced a new model of state building namely ethnic-based federal system in 1991. This has been translated into practical reality through a redrawing of the country's politico- administrative map largely along ethno-linguistic lines. To its credit, the incumbent government under-took 'radical' and 'pioneering' (Turton, 2006:131) reforms in the state structure and explicitly proclaimed a fundamental break with the country's long history of centralized authoritarian governance to ensure their self-government and to help nations and nationalities retain their cultural distinctiveness The Constitution of the FDRE establishes nine "self-governing" ethno-regional (Art. 47) and two city administrations. Oromia and Somali regional states are two of the nine regions. Ethnicity is the key factor in establishing the regions, and sub-regional units in the multi-ethnic regions.

Indeed, the 'ethnicization of the country's political landscape', helps historically marginalized and disadvantaged ethnicgroups to attain self-governance and equality (Merera G., 2003: 110) ${ }^{4}$.

The Ethiopian ethnic federalism and the recognition of the right to self-determination including secession are meant to avoid ethnic domination and lay a favorable condition for lasting peace. However, in the years of its implementation, the major challenge remains to be unprecedented ethnic conflict and border disputes in Ethiopia in general and in border lines of Oromia- Somali Regional States in particular (see Abbink, 2011; Asnake, 2011; Hagmann and Mulugeta, 2008; Schlee and Shongole, 1995). As a result, the reconfiguring of the Ethiopian state along ethnic lines has

\footnotetext{
1 The only major exception in this regard could be the Borana Oromo who practice traditional religion.

2 This refers to the assimilation of some Somali and Oromo clans by their neighbors through a long period of interaction. Because of the assimilation, some of the concerned clans could adopt a new Oromo or Somali identity - or maintain a dual identity of both the Somali and the Oromo. For instance, the Garre clan in the Borana region uses the Oromo language, but due to its Islamic religion and genealogy identifies itself with the Somali (Farah 1996: 124, see also Asnake, 2009:181).

3 The Borana and Gabbra are in southern Ethiopia and northern Kenya. The majority of them are found within Ethiopia. The Garre, on the other hand, are found within Ethiopia, Somalia and Kenya. In terms of language, all of the clans predominantly speak Afaan Oromo, while the Garre of central Somalia speak a Garre dialect known as Garre Koffar (Belete 1999: 30; see also Asnake, 2009: 182).

${ }^{4}$ On the contrary, some critics contend that the restructuring of the state along ethno-linguistic criteria was motivated by TPLF/EPRDF elite's interest of hegemonic control of the state and to reverse Amhara elite's historic dominance. It is merely an opportunity for EPRDF dominance which fell short of its rhetoric, and in some cases produces additional, unforeseen problems and can hamper to achieve effective self-governance and sustainable peace see for instance, Merera Gudina, (2003) Competing Ethnic Nationalism., 123.
} 
attracted mixed reactions and contending views. Hence, the practice of ethnic federalism in Ethiopia is yet a matter of debate, whether it's a remedy or a curse for long existed ethnic conflicts within the country. Thus, some scholars argue that the system is a panacea for ethnic conflict while others counter argue that the new system exacerbates ethnic conflicts. As this study focuses on the conflicts between Oromo and Somali ethnic groups which are the members of the Ethiopian federation and the prevention of these conflicts through institutionalizing conflict EWS and response systems, it is important to highlight the existing competing perspectives. Accordingly, the two contending views are discussed in the next sections.

\subsection{Contending Views on Ethiopian Ethnic Federalism}

There are varied conceptions about the values of ethnic federalism. Some scholars and Ethiopian authorities are in favor of ethnic based federalism with assumption that it is a panacea for the longstanding ethnic conflicts in Ethiopia. However, others contend that such federalism complicates the fabric of the country and instigates endless ethnic conflicts.

\subsubsection{Federalism as a Panacea for Ethnic Conflicts}

The perspective that defends the ethnic federal system promotes the view that ethnic federalism is a way towards democratization and development by fairly managing ethnic diversity and resolve ethnic conflicts. The advocates of this perspective consider it is a panacea to the age-old national oppression and dominations; and hence they commend the implementation of ethnic federalism as appropriate measures to rescue the country from the alleged impending disintegration. This perspective also contends that it is a novel ethnic policy to demonstrate the regime's commitment to promote equality of nations and nationalities and peoples' as a strategy to forge diversity through voluntary federation which would ensure democratization (Salih \& Markakis, 1998; Young, 1998; Alemseged, 2004; Fasil, 1997; Mengisteab, 1997). Likewise, others also argue that the federal system attempts to balance varied interests including maintaining national unity, preservation of ethno-linguistic demands, alleviation of ethnic inequality and marginalization by granting the right to self-determination, development of one's culture and language and self-government which has been guaranteed in the constitution. Hence, the ethnic groups in the country have largely welcomed the right to speak and write in their own language and use them for local administration. They also appoint local officials from their own ethnic group for self-administration (Hagmann and Abbink, 2011: 583). Moreover, Mesfin (2011) argued that ethnic federal system has been used as a principle of government for reasons such as better economic and security opportunities and accommodation of different identities in the political spheres. According to this view ethnic based federalism is a multilayered government structure which combines elements of unity and diversity, shared rule and regional self-rule in which people are free to preserve and promote distinct identities, national sovereignty and regional autonomy and enhances the political participation of the population. Hence, many hitherto marginalized minorities groups were given representation at federal and regional levels, centralization and decentralization of power within a larger political system (Mesfin, 2011). Furthermore, others also argue that ethnic federalism is intra-governmental decentralization; and devolutions are some of the most cited forms of devolving power to lower levels. Therefore, within this federal form of governance, sub-national governments (regions) with clearly defined territorial boundaries usually enjoy considerable degree of autonomy from the center (Lovies, 2000; Ayenew, 1998; Odowa, 2009:13). The advocates anticipated that the new system would end the dominance of the state power by a single ethnic group and realize self-administration.

\subsubsection{Federalism Exacerbates Ethnic Conflicts}

The other perspective contends that ethnic- based federalism is exacerbating localized inter-ethnic tensions and conflicts in the country. Equally, there are groups which view the short comings and entrenchment of ethnic federalism model as a dishonest move at best and a political trick at worst, with a malicious intent, to destroy the country and hence they bitterly resent it (Aalen and Tronvoll, 2009; Berhanu, 2007; Aelen, 2006). Likewise, other scholars also put forward their argument that the new system excludes many other essential concerns such as the long history of ethnic mobility, intergroup relations and integrations in the country and redrawing ethnic based boundaries between groups has been generating ethnic based boundary conflicts (Asnake, 2010; Tsegaye, 2010; Vaughan, 2003). Skepticism about the use of federalism in managing ethnic conflicts relate in part to the susceptibility of multi-ethnic federations to fragmentation. The USSR, Yugoslavia and Czechoslovakia, which collapsed after the end of the Cold War, exhibited vulnerability of multi-ethnic federations to conflict and fragmentation (Gagnon 2001: 320; Asnake, 2009:46). Extending his argument, Asnake claims that the major problems refer to the impossibility of making ethnic and administrative boundaries congruent. This tends to engender tensions and conflicts in the relationship between local/regional majorities and minorities. Thus, restructuring multiethnic states into ethnic federations tends to generate intra-federal (violence) conflicts. As a result, the debate has continued unabated for a long time now with a little hope for consensus in the foreseeable future (Asnake, 2009: 46). On the other hand, one can sense that in the Horn, the conflicting parties usually belong to different ethnic groups. Though some questions whether the conflicts in the region are caused by differences ascribed to ethnicity, never the less, it is undeniable that they are contributing causes and more often than not are exploited by the contending political elites (Assefa, 1996).

I argue that the recognition of equality, cultural and linguistic autonomy has been positively contributing in paving the way for sustainable peace in the country. While realizing the positive effects of establishing local level structures through decentralization of power and resources to local governments, it is, however, important to take a critical look at current modes of thinking and practices at the local level regarding its effect on local ethnic conflicts. Abbink (2006:390), argues that "the post 1991-regime (...) basically only, decentralized" the problems by defining the sources of conflict to be on the local and not national level”. Thus, decentralization is not enough to avoid ethnic conflict. It 
becomes clear that the question of how access to state resources is regulated is much more important than the question "who has access to state resources?" Another drawback of power exertion from above is that it has destroyed many forms of traditional mechanisms of conflict resolution. Since all resolution of conflict has to conform to government measures, grassroots organizations are usually not consulted, even though they have strategies of avoiding conflict that are more effective than the state proposals (Abbink, 2006: 401). Henceforth, the post 1991 regionalization provided incentives and conflict along the common borders of both regions was unresolved due to different potential causes and multiplicity of actors that frequently take away the lives and property.

\subsection{Federal Restructuring and the Oromia - Somali Border Conflict}

The federal restructuring of the country has brought political significance to the question of whether a clan is from Oromo or Somali (Schlee and Shongolo 1995: 8). Federalism and ethnic conflicts are generally about politics of States. In the Ethiopian context, economic, social and political forces intertwine with ethnic conflicts attributed to the federal restructuring of the country. For instance, John Markakis argues that in the Horn of Africa, the State, as it controls the production and distribution of material and social resources, has become the object and instrument of conflicts (1994: 212). The regime has constitutionally divided the country into nine autonomous regional states. ${ }^{5}$ These regional states organized their lower levels of administrative units (zones, districts [woredas], and kebeles). Oromia and Somali regional states are two of the nine regional states. As soon as the ethnic federal structure was put in place, the Oromia and Somali regional states engaged in protracted claims and counter-claims of territories along their nominal but unclear borders. Especially in the pastoral areas that characterize most of the Oromia and Somali regional states borders, where the livelihood of the people depends on movement, borders are practically permeable. Likewise, some scholars also argue that inter-regional boundary conflicts between the Somali and the Oromia were intensified particularly in pastoral and agro-pastoral areas following the post-1991 period as the result of the territorial reconfiguration and regionalization of the country along ethnic lines (Fekadu, 2011; Asnake, 2009:182; Hagmann and Mulugeta, 2008).

Next to the introduction of the federal system, Oromia and Somali regions share long borders. Five zonal administrations from Oromia side and six zonal administrations from the Somali side. The territories where the claims and counter claims prevails, include grazing fields, watering points, kebeles, towns and revenue centers. These contested border areas stretch from Mi'esso District in the north-eastern plateau to Moyale District in the south eastern lowlands that affects vast areas. The north-eastern landmass comprises West Hararge, Eastern Hararge and Siti, Negob and Fafan zonal administrations from the Oromia and the Somali regions respectively. The Oromo groups such as Ittu, Nole and Jarso reside in the area either neighboring or intermingled with the Issa and Hawiya clans of the Somali. The south -eastern part consists Bale, Eastern Guji and Borana zones of Oromia region and Afdher, Liban and Dawa zones of the Somali region. The Oromo groups such as Arsi, Guji and Borana and the Somali clans such as the Gurra, Marrehan, Digodia and Garri predominantly inhabit along the borders of these areas. The situations in these indistinct border areas are known for their frequent conflict between the two regional states. Thus, the new line of division between the Oromia and the Somalia regions was considered enormously important for both the local actors and regional authorities for consolidating the territorial and political identity of their ethnic regions. In other words, the conflict now has regional and ethnic dimension between the Oromia and the Somali regions. When local dispute coincides with the boundaries between regional states, conflicts between ethnic groups transform to conflicts between regional states (Asnake, 2009, 187). This caused a prolonged conflict along the adjacent areas of Oromia and Somali regional states. It has worsened ethnic tensions among local agro pastoralist and pastoral areas from 1991-2018.

As this Article tries to show, the boundaries are not clearly demarcated and remained blurred as a result of which frequent conflicts continued resulting in numerous humanitarian and material crisis. On top of that, the introduction of the new federal system was not accompanied by strong and comprehensive conflict prevention, early warning and response institutions to contain, mitigate and prevent conflicts from escalation to destructive outcomes. Thus, the local traditional resource conflicts have been transformed into more complicated politics and they have fueled local conflicts in the contested districts into destructive crisis. BBC News broadcast stated that Ethiopia's political arrangement - federalism structured along ethno-linguistic lines - dictates that ethnic borders are also usually political ones. Critics argue that this structure is a tinder box that allows minor conflicts to escalate (BBC, 15 September 2017). In addition, the current political elites have also tried to secure as large territory as possible from resourceful areas such as water points, grazing areas, trade routes and towns under their jurisdiction. They seemed to mobilize local people along the ethnic lines. In some areas, local people have started permanent claims over areas they had shared with their neighbors or lived side by side in the past. This kind of local conflicts were previously confounded to just rural areas and now they have spread to major towns, settlements and revenue centers such as Mi'esso and Moyale towns. Increased division and hostility ruined the peaceful co-existence among different neighboring communities in these areas. The existing local resource conflicts have taken political dimensions mainly due to the state political and structural changes in the country (Getachew, 2006). Likewise, the new system seemed to politicize the existing difference and added a dimension of "us" from "them", which diminished the elements of similarities and magnified the differences. Hence, the conflict demonstrated the potent force of ethnicity in creating hostilities and conflicts between dichotomized groups, once activated for political or economic motives.

On the other hand, following the establishment of the ethnic based federal system in the country, various ethnicbased political organizations have become operationally active in these border areas. Some of them were also created

${ }_{5}^{5}$ According to Article 47 of the FDRE Constitution, the nine regional states are the state of Tigray, Afar, Amhara, Oromia, Somali, Benshangul/Gumuz, Southern Nations, Nationalities, and Peoples' Region, Gambella and Harari. 
within or as a result of the new system. Among these organizations were the Oromo Liberation Front (OLF) 6 , Oromo Peoples' Democratic Organization (OPDO), Democratic Unionist Party (DUP), Issa Gurgura Liberation Front (IGLF), and Ethiopian Somali Democratic League (ESDL). All of them have contributed in one way or another to the intensification of the conflict either rhetorically or practically. In general, during the years following the commencement of the ethnoregional administration, the issue became political strife resulting in gaining or losing more territories. Using any possible means they try to win the game and thereby defending their rights of territorial integrity from encroachment. The conflict is political, it is not just about recourses anymore, and it is about having administrative power and control over land.

\subsubsection{The Transfer from Competition for Scarce Resources to Territorial Claims as a Cause of Conflict}

Mancini (2013) argues that territorial disputes remain serious challenges to peace and stability. In fact, interstate disputes, those over territory tend to lead to armed conflict. A mix of political and economic interests, normative reasons, and competition over scarce natural resources have been drivers of conflict over disputed territories (Francesco Mancini 2013:1). Repetitive redrawing of administrative and political boundaries is an attribute of institutional instability that leads to different and frequent claims (Asnake, 2009:187). Moreover, delimitation and demarcation of borders between the ethno-national states has been the most challenging exercise in the ethnic based federal set up in Ethiopia (Fekadu, 2011, Asnake, 2010; Asebe, 2007). Thus, the recent territorial division between the Oromia and the Somali regions was considered enormously as a challenge. Hence, claims and counter-claims over territories around the borders of these regional states in Ethiopia became the center of conflicts (Fekadu, 2011). Parallel to territorial contestation and negotiation between the two ethno-national states, neighboring pastoral communities who belong to either of the ethnic groups fight on the ground. Pastoralists on both sides blame that each regional government has used regional militia and police forces in the fight. In other words, militia and police forces armed by both governments have been fighting under the guise of local people but this has been strictly concealed at the administrative levels. Overall, the Oromia--Somali conflicts have been disputed in a number of cases and have remained with both change and continuity over time. A key informant depicted that,

The contemporary nature of the conflict between the communities along the borders is changing over time. In the pre-1991 period the conflict was over pastures and water points that has directly attached to the pastoralist way of livelihood. The current situation is however, distinct from the old ones in that it is not merely trying to access the pasture and watering points rather pastoralists tend to spend days in the resource sites and soon raise questions of ownership where in the regional state's border where the resource site lay and claim that it belongs to them. In addition, local government officials are the major actors in promoting such claims and mobilize their respective ethnic groups. ${ }^{7}$

This is supported by the works of Said (1997) that explains the conflicts over water and pasture are gradually introducing the element of which group should permanently own resource areas in the virtual expansion to the other resulted in the ethno-pastoral territorial claims. Hence, traditional conflict over scarce resource has been complicated with an upsurge of territorial claims (Said, 1997). In other words, the fact that the border between the Oromia and Somali regional states has not been demarcated means that it presented a fertile ground for conflict to crop up around the border areas. An informant from Oromia region stated that,

Somalis have strong appetite for expansion along the border areas through illegal settlement schemes and tried to change demography of the area between both regional states. Moreover, they are making tactical shuttling and are deliberately delaying the implementation of joint discussions and agreements including the results of the 2004 referendum. Furthermore, they change their positions and obstruct the agreements reached for border demarcations. The act of the Somalis is beyond the competition for resources but compounded with political motivation to control the area. This is backed by the regional government. 8

The informant added that the potential conflict clouds are still hovering in the sky of the borders of Oromia and Somali regions so long as the Somali regional state government adheres to its unabated claims of territories over its neighbor (Oromia). ${ }^{9}$ Moreover, another informant, also explained that

In the earlier periods, conflict along the adjacent areas of both regions is commonly used for grazing and watering purposes. Both communities tend to resolve their disputes through customary mechanisms. However, since the introduction of the new federal system, the nature of the conflict was gradually transformed from grazing and watering disputes to controlling bordering areas through expansion which have manifested in the form of illegal settlement schemes and erecting flags crossing counterpart's border. Administrative boundaries are not clearly demarcated by the regional and federal governments. This has immensely triggered frequent territorial claims and conflicts. 10

Likewise, the informant from the Somali region explained that

"... The Oromo and the Somalis experience conflicts even long before the introduction of federal system and they resolved them through their respective customary mechanisms. But, since the introduction of the federal system, the conflicts have become more frequent and violent along the borders. The livelihood of the pastoralists would force them to move and cross borders to access water and grazing fields." 11

\footnotetext{
${ }^{6}$ The Oromo Liberation Front existed in the 1970s and actively operate as well in the area in the post 1991.

7 Interview with Official from Ministry of Federal and Pastoralist Development Affairs, August 7, 2015, Addis

${ }^{8}$ Interview made with Oromia government official, January 10, 2016, Addis Ababa.

9 Ibid

${ }^{10}$ Interview with Oromo elder in Mi'esso wereda, February, 16, 2016.

11 Interview made with Somali government official, February, 20, 2016, Jijjiga.
} 
From the view point of informants, it is observed that the intensity of conflicts in the post 1991 has been more frequent and violent and the traditional ways of resolving disputes related to resources competition have been weakened. Moreover, the absence of clear demarcation along the contested areas has contributed to territorial claims over times. As discussed above, making clear demarcation could not dodge from challenges. Watkins and Fleisher's (2002) observation on the fluidity of boundary names and shapes in the Horn of Africa finds its typical ideal realization in the case of the Oromia- Somali Regional borders. Up to this day, there has not been geographic map featuring the correct politicoadministrative boundaries of zones and districts between Oromia and Somali Regional States in accordance with the reality on the ground. In this regard, Abdi (2017) also argue that states ethnic regionalization under federalism and the need to demarcate borders between both regions came up with challenges from the very start that both regions laid claim to some of the same borderline areas as their own. The issue of instituting territorial demarcation is re-awakening and sharpening the old and traditionally dormant ethnic conflict between the two sides. ${ }^{12}$ As discussed earlier, the system pursued in the post 1991 in the country posits ethnic federalism and the regionalization process involves ethnic groups who ethicized territorial demarcation. Hence, one could observe that such a process could be a conflict factor that generates anxiety between both regional states.

After a decade of territorial contestations and at the height of the violent conflicts, the referendum was carried out in October 2004 pursuant to the agreement reached between both regional states. The referendum was believed to decide to which administrative region (Oromia or Somali) people in the contested areas would want to be included and to resolve the claims and counter claims between Oromia and Somali regions. The HoF ${ }^{13}$, which is responsible for resolving interregional conflicts, instructed the NEBE to hold a referendum in 420 kebele along the contested borders of the Oromia and the Somali regions including the highly contentious, politically and economically strategic districts of Mi'esso and Moyale. Accordingly, the referendum in Mi'esso was conducted successfully in 15 kebeles out of which 14 voted in favour of Oromia and 1 (one) voted for Somali (NEBE Report, 2004). However, soon in the aftermath of the referendum, allegations and claims continued to challenge the result of the referendum (as shown below). On the other hand, with regard to the referendum around Moyale, the process was taken "successfully" in other kebeles, but it failed to materialize in nine kebeles around Moyale and surroundings due to procedural reasons like; Moyale 01, Moyale 02, Chamuk, Kebenawa, Bede, Buledi, Moyale Elgof, Maddamigo and Meleb. NEBE and HOF reported that the reason was due to disagreements between the two regions on a number of issues such as disagreement over election of public observers, registration irregularities (brining people who are not residents in the area), displacing people from one area to another for the sake of election and mutual suspicion (NEBE Report 2004:6). Subsequently, these areas were left to the dual administration of the two regions with competing and at times conflicting jurisdictions. This left a contested boundary area for the Borana (Oromo) and Garri (Somali) people living in the area.

Local Oromo and Somali officials, however, blamed each other for the cancellation of the referendum. An Oromia official alleged that the referendum was 'cancelled because of the fact that the Garri brought thousands of people from other areas including Kenya and Somalia so that they could prevail over the Borana and secure the ownership of the town. ${ }^{14}$ In contrast, officials of the Moyale Somali woreda allege that the pressure from Oromo officials at the regional level, who feared holding the referendum as planned, meant Oromia would lose Moyale, spoiled the referendum. ${ }^{15}$ After the failure of the referendum and the situation remains tense and incident could trigger violence in the area, the federal government deployed federal police to deter violence.

Both Borana and Garri informants reflected that they were unhappy with the results of the referendum; while most of the Borana completely condemned the principle itself, the Borana elder stated that

We didn't agree on the demarcation. The Somali took our historical land. We are never happy about it. We are still fighting for the lost grazing land and deep well Gof and Lae that was dug by the Borana long time ago. We cannot access it now, we allowed the Garri people to stay on our territory when they came as a guest from Somalia, now they took it. 16

On the other hand, the Garri informants have also reflected their unhappiness with the result of the referendum and they still claim some areas and they reject the Borana claim. They were disappointed with their loss of some kebeles across the border and those particularly in Moyale town and its surrounding. An elder from Garri stated that "the Borana want all the land, it is never enough for them. We are claiming our historical territory too. Our people had left some of the areas during the Ethio-Somalian war and we are reclaiming that again"17 Thus, it was observed that the result of the referendum had neither been implemented nor the existing territorial claims and conflicts had been halted, though it has temporarily decreased the magnitude of the conflict. Beyond the numerical result of who won what, the referendum did not result in peaceful sharing of resources and co-existence of the neighboring Oromo and Somali peoples. In some areas the result of the referendum itself became part of the on-going conflict. In many areas where the border was delimited in accordance with the referendum, the previous good social relations that had existed between people of differing ethnic identity deteriorated. For example, the Borana and Garri fought three deadly conflicts over their borders in June 2008, February 2009, and July 2012 around the bordering districts of Arero, Udet and Moyale. As a result, some 80,000 people were internally displaced by the conflict (IDMC, 2009: 10; See also Fekadu, 2011: 10).

12 See Imael Abdi, 2017, Somali blogger in his Article, Shedding Light on the recent violence in the border areas between Somali and Oromia regions of Ethiopia. aigaforum.com/article2017/somali-oromia-border-issue-explained.htm.March 11, 2017 accessed April 15, 2017.

13 See Article 62 of the FDRE Constitution.

14 Interview with Official in Oromia Moyale woreda, September 15, 2015

15 Interview with official Moyale of Somali woreda, September 15, 2015.

${ }^{16}$ Interview with Borana Oromo elder in Moyale, September 15, 2015.

17 Interview with Garri- Somali elder in Moyale, September 15, 2015. 
Both Oromo and Somali have been attempting to re-structure and create new kebeles, woredas, and zonal administrations along the un-demarcated border areas. In this regard, Hagmann stated that the subdivisions of Somali have been changed several times, often due to local clan groups claiming their own woreda (Hagmann, 2005:12). The assertion of Hagmann does not seem convincing for the reason that in the current context of the conflict along the bordering areas, since both regions provoked the design as a strategy to control and own more territories and incidentally attempted to change the demography of the area. However, it could be a contributing cause to trigger conflict. For instance, Oromia regional state has restructured weredas which border with Somali region in West Hararge and Borana zonal administrations. Gumbi Bordode was the newly established wereda in western Hararge as a result of the claims and counter claims of territories around Mi'esso. Likewise, Chamuk, Wachile and Guchi districts were formed newly as a result of the territorial claims between Borana and Garri around Moyale district.

On the other hand, the Somali Regional state restructured and increased the number of new weredas along the contested areas. For instance, Hadhagaale, Geblalu and Gota Biki are newly structured Weredas in Shinille (Siti) zone around Mi'esso of Oromia. The Somali regional state increased the number of zonal administrations from nine to eleven. The former Liban zone becomes two zones; the newly structured zone is named as Dhawa comprising four districts; Moyale, Hudet, Mubaarak and Qadhaadhumo. Both Mubaarak and Qadhaadhumo are newly structured Weredas as a result of claims over territories around Moyale of Oromia. ${ }^{18}$ Hence, the boundary between the Somali and Oromia Regions has been disputed, leading to ambiguity over the status of border areas. In addition, a key informant emphasized that “...The reconstruction of residential areas in the name of development on the contested kebeles around Moyale will further trigger future conflict. ${ }^{19}$ Moreover, most informants from Borana and Garri claim that the main reason for most of the contests that they have had since 1991 were border issues, claims and counterclaims over territory along the border. The conflict has been there since long time mainly due to land and water resource. But now it became all about territorial ownership. Subsequently, another data obtained from the archive of Oromia Administration and Security Bureau revealed that conflicts along the bordering areas of Bale zone of Oromia comprising six districts; Beltu, Guradhamole, Rayitu, Dawe Qachen, Dawe Sarar and Madda Walabu and Filtu and Afdher zone of Somali were areas where territorial claims, border expansion and illegal settlements prevailed. Furthermore, conflicts have recurrently ascended over expansion of territory and grazing lands because of the absence of clear border demarcation and these conflicts have been coupled with theft and raids of cattle. For instance, in Eastern Guji zone in some areas the observation data supported by interviews and archival sources showed that the Somalis crossed 30 kilometers into the territories of Oromia, for instance in the Arero districts of Borana zone of Oromia (Oromia OBAS Archive, 2016).

In this regard, media sources such as All African Report, citing the representatives of Oromia who said an invasion of their region by a special Liyu Police and militia force stated that the causes of deadly border clash have also been contentious territorial subject. In contrast, Somali officials on their part referred to situation as some aggressive regional police targeting unarmed peaceful Somali civilian (All African Report, October 6, 2017). Though the officials counter argued, one could observe that the bone of contention between them is territorial claim. BBC in this regard reported that the long-standing conflict between the large regions has its roots in territorial competition (BBC News. Com, 6 October 2017).

A key informant from the Somali region reported that [...] the major cause of conflict along the adjacent districts was conflict over territorial borders which claimed numerous lives and properties, much of the districts and kebeles of the Somali region were wrongly occupied by the Oromo communities along these borders since the 2004 referendum. However, the informant did not mention particular districts but listed the names of zones (Siti, Nigob, and Liban) experienced most. ${ }^{20}$ From both sides of the same equation, observation could be made that, on the one hand, the nondemarcation of the contested areas was used as an opportunity to claim and counter claim territories of counterpart areas and this gave way to the disruptive communication among the communities and further exacerbated the conflicts. On the other hand, there was no proper conflict prevention, management and resolution mechanisms in place that would institutionalize conflict early warning and response systems.

In fact, the root of the conflict lies in a volatile combination. But politicization and ethnicization of boarders is one among the factors that justifies the transfer of causes from scarce resources to territorial borders. This is accompanied by the symbolic meaning given to the Oromia-Somali border, and its lack of an official demarcation. Disagreements over exactly where the Oromia-Somali border should lie have resulted in several referenda, but full demarcation has never occurred, contributing to ongoing strains. Moreover, the forced relocations in 2018 are the latest fallout of simmering conflict along the border between Ethiopia's Oromia and Somali regions. Those tensions have boiled over in recent weeks, resulting in hundreds of deaths and tens of thousands of displacements.

\subsubsection{Selected Cases Explaining Oromia - Somali Conflict: The Case of Miiesso District}

In this following sub sections, I will discuss two cases -Mi'esso and Moyale - in order to explain the Oromo-Somali conflict around the borders of both regional states. These districts are selected following their similarities and differences. Their similarities lay on the fact that both of them have been conflict prone areas and have experienced frequent conflicts since the regionalization process in the post 1991.Both districts refer the same name for both regions. That is Mi'esso district of Oromia and Mi'esso district of Somali on the one hand and Moyale of Oromia and Moyale of Somali on the other. In both districts, the 2004 referendum was conducted along contested kebeles. The Mi'esso referendum was "successful"

18 The name was derived from Dawa River where the Borana used to water their cattle. The new structure is an attempt to blockade the movement of the Borana cattle towards the river.

${ }^{19}$ Key informant Interview, Moyale (Oromiya), Sept.15, 2015

${ }^{20}$ Interview Somali official, Jijjiga, February, 20, 2016. 
but allegations and claims followed subsequently after the announcement of the results. The referendum in Moyale, in certain kebeles, failed due to procedural irregularities. Hence, conflicts have continued until recently and aggravated since post 1991 in both districts. Both districts are geographically strategic for the regions. Mi'esso is found on the outlet of the railway line that connects Ethiopia to the port of Djibouti and Myole (Oromia) is a border town that connects Ethiopia and Kenya. Their difference is that Mi'esso district is located in the eastern most in which the Ittu/Nole Oromo groups confront with Issa of Somali clan whereas Moyale is located at the southernmost where Borana Oromo and Garri of Somali. Dual administration of Oromia and Somali regional states in Moyale town could be a reason for unabated conflict in the area since 1991. Henceforth, both districts are used to explain the boundary disputes between Oromia and Somali regional states.

Geographically Mi'esso district is located $291 \mathrm{~km}$ to the east of Addis Ababa. It is found in the lowland area next to the Awash valley, nearby the Hararge Mountains. The railway that connects Addis Ababa to Djibouti and the highway that connects Eastern and central Ethiopia passes through Mi'esso. Due to the existing contestation over that area, both Oromia and Somali regional states use Miesso as the name of the two neighboring districts belonging to the two regions. Both Mi'esso districts are inhabited by Oromo and Somali. The two major Somali clans inhabiting Mi'esso are Issa who are largely pastoralists and Hawiya who practice mixed farming Most of the Issa speak only Somali language, while Hawiya and other minority Somali clans in the district speak both Somali and Afan Oromo. The Oromo local groups include Ittu, Alia, Noolle, and Obora. The majority of Oromo clans in the district are agro-pastoralists and sedentary farmers. They speak Afan Oromo. In the towns, apart from Somali and Oromo, there are also small number of Amhara, Gurage, and other minority ethnic groups (Getachew, 2006; Shide, 2003). The district residents draw their livelihoods from the livestock rearing and mixed farming under a harsh ecological environment, where inadequate rainfall and recurrent droughts are common. During the Derg regime Mi'esso district was under Asabe-Tefari sub-province (Awraja) of West Hararge Province. Following the formation of ethnic-based regional states in 1991, both the Oromia and Somali regional states started to claim and counter claim over the ownership of the district. Consequently, the district was divided into two and put under Oromia and Somali regional states' administrations with no clearly demarcated border between them.

Both regional states continued expanding their sphere of influences to the other towns and rural kebeles in the district. When these developments took place shaping the prospects for conflicts no early response was given. During the transitional period, the government institutions at all levels were weak. The district hosted several ethnic-based political parties among, OPDO, OLF, IFLO forces on the Oromia side, and IGLF, DUP, and later on ESDL on the Somali side. All these political parties have been directly and indirectly involved in the dispute (Shide, A.2003; Getachew, M. 2006).

Obviously, ethnicity has become the primary means of ethnic mobilization. A key informant explained that:

The claim of each of the ethnic-based political forces (especially OLF, IGLF, DUP, and after the transitional period OPDO and ESDL) to include Mi'esso and its neighborhoods into their respective jurisdictions have spoiled the peaceful co-existence between the residents of Mi'esso and especially between Hawiya (Somali) and Ittu (Oromo). Their relationships have been spoiled by the growing Oromo and Somali nationalism. Initially, this situation has affected the areas jointly inhabited by Hawiya and Ittu clans. As a result, the two groups started to separate their grazing land, then continuous violent conflicts took place between the two....21

The referendum took place in October 2004. Residents of fifteen contested kebeles around Mi'esso casted ballot to determine to which administrative region they wanted to belong. Accordingly, fourteen kebeles voted in favour of Oromia and only one kebele voted to be administered by the Somali regional state (NEBE Report 2004; OBAS Report, 2016). Though the Somali regional state officially accepted the overall result of the referendum at the time, the its officials now argue that they rejected the result of the referendum.

Pertaining to this, Somali informant stated that:

The referendum was conducted when the number of Somalis who were in the area were limited due to their seasonal movement, the Oromia Regional State exploited the opportunity and won Mi'esso town as a result. Somalis did not accept the outcome of the referendum and claimed Mi'esso town especially the surrounding Kebeles. ${ }^{22}$

The Somalis retrospective argument uses pastoral way of life - seasonal migration as a reason for their loss in the referendum. However, not only the Oromo informants argue against the accusation, but also the official result from the $\mathrm{HoF}$ proves the falsity of the allegation from the Somali side. ${ }^{23}$ The Somali local officials were quite open that the Somalis were regretting the loss of territory in the referendum ${ }^{24}$. Actually, that was why the officials from Oromia side stated that the major cause of the conflict between Oromo and Somali groups around Mi'esso area was by no means grazing and water points but control of the territory including the Mi'esso town by the force which lost the vote through referendum. Mi'esso's economic importance due to its location as an outlet to Eastern Ethiopia and Djibouti has been usually raised in attracting Somali attention ${ }^{25}$.

\subsection{Territorial Claims and Conflict}

The territorial claims and counter claims between Oromia and Somali regions were discussed in general terms above. The focus in this section is to substantiate the earlier discussion with an account from Mi'esso. Talking about the causes of the conflict and territoriality, a key informant from Miêsso of Oromia elucidated that

\footnotetext{
21 Interview with official in Mi'esso of Oromia, February,17, 2016, Mi'esso Town.

${ }^{22}$ Interview with former Somali Mi'esso Woreda official, Mi'esso town, February, 17, 2016.

23 Interview with Oromo elder Mi'esso, February, 16, 2016.

${ }^{24}$ Interview with Somali MiesoWoreda official, Mi'esso, February, 17, 2016.

25 Interview with member of the parliament formerly resident in the area, August, 2016
} 
The Oromo-Somali conflict in the post-1991 around Mi'esso revolve mainly around two major causes. These are competition for resources due to environmental changes year after year and the push of one ethnic group to cross into the territory of other groups and resistance over controlling that area. The second cause is related to expansion of the Somalis into the territory of the Oromo as clearly seen over the past two decades. This created frequent clashes between Oromos and Somalis along the borders. The government has tried to curb the problem by conducting peace referendum in 2004 but no demarcation has taken place. In the aftermath of the referendum, following the announcement of the result, the conflict again erupted in the area. ${ }^{26}$

In addition, another informant said that Somalis have strong ambition to control the fertile areas in every direction because their land is now becoming less hospitable to their livestock. As a result, they raise the issue of territorial claim and start to expand into two directions to have more land; the directions are in the border areas of Afar and Oromia regional states. ${ }^{27}$

In addition to this, an Oromo elder stated that the conflict "is purely [attributed to] the expansion policy of Somalis towards Oromo land in the name of administrative boundary". Both informants recount how the Somalis evacuated the Afar from their place in the past thirty years and now how they wanted to do the same to Oromo. They argued that had the problem been about administrative border, it would have been resolved through the 2004 referendum. "The Somalis still do not accept the result of the referendum and they claim the town of Mi'esso. Their design is to the territories they claim by creating tensions in the surrounding". 28

FGD participants in Mi'esso further explained that the Somali elites at kebele, district, zone and region levels have repeatedly devised new and divergent mechanisms to create tensions and conflicts, sometimes simply due to their personal dissatisfactions in their political positions. Some of these mechanisms of creating tensions and conflicts in the community were encouraging illegal settlements and building schools in the contested areas. The other was hoisting of the reginal flag outside of their respective administrative regional boundaries which had its own implications regarding entitlements of ownership to such areas. In addition to this, a local police officer described that "... territorial claims and conflicts along the boundaries of the two peoples in Mi'esso district are in most cases triggered and accompanied by other factors such as influx of arms, unemployment and deficit in good governance from both sides of the regional state borders." ${ }^{29}$ From the above discussions, it should be clear that multiple factors instigated conflicts even though it is usually called conflict over contested borders.

\subsubsection{Selected Cases Explaining Oromia - Somali Conflict: The Case of Moyale District}

Geographically, Moyale is a border town between Ethiopia and Kenya, has strategic significance as a gateway to Kenya from southern Ethiopia. An asphalt road connects it to Addis Ababa. Like other towns in southern Ethiopia, the development of the Moyale town was associated with the expansion of the Ethiopian State at the end of the 19th century and the formation of administrative and military centers in conquered territories. The Ethiopian town of Moyale was initially a military post established to control the border of the Ethiopian empire against the British in Kenya. The Moyale town became the capital of Moyale district in the 1930s. This was changed to the Oromian Moyale district in 1991 . In 1995, the Somali national regional state established its own Moyale district, inhabited by the Garri, and opened administrative offices in the same town, Moyale (Fekadu, 2011; see also Bassi, 2010). Since then, political control of Moyale has been contested between the Borana and Garri at the local level, and by the Oromia National Regional State and Somali National Regional State in the national political arena. At present, there are two competing administrative structures based in the same town, one for Oromia and one for Somali. The competing state structure is a real challenge for the residents of Moyale.

Most existing literature indicates that the conflict over Moyale has often been between Borana Oromo and Garri Somali pastoralists at the local level (Fekadu, 2011; Asnake, 2010; Melkamu, 2016:48; Tigist, 2014; Gololcha, 2015). The Gabra clan are also another major actor. The Borana, Garri and Gabra predominantly live in the former Borana ${ }^{30}$ province. All the three groups straddle the international border to northern Kenya (Asnake, 2010:620). The Garri also inhabit in the Southern Somalia. In the present politico-administrative setting in Ethiopia, the Borana and Garri are found in the Borana and Dawa ${ }^{31}$ zones of Oromia and Somali regional states respectively (Fekadu, 2011; Asnke, 2010:620). The Gabra are divided between the two, though the majority of them live in Oromia. Linguistically, Afan Oromo is the lingua-franca of the region, though the Garri have increasingly adopted Somali recently. The relationships among the three groups have been reconfigured and politicized over the course of many decades. Actually, the dispute between the Borana and Garri goes back to the Italian occupation of Ethiopia (1935-41), when Garri supported the Italians and the Borana remained loyal to Ethiopia. The conflict was intensified and took a territorial conflict shape during the conflict between Ethiopia and Somalia following the latter's independence in 1960. This period politicized inter-group relationships among these three Afan Oromo speaking groups with a lasting impact (Gebru, 1996; Getachew, 1996, 2002; Markakis, 1987; Schlee, 1989; Yaqob, 1997 cited in Asnake, 2010: 620). However, it is the post-1991 Ethiopian ethnic based administrative decentralization that caused contestations between the three mainly over Moyale. Ethnic regionalization required the Garri and the Gabra, who

\footnotetext{
26 Interview with an official from Oromia- Mi'esso wereda Administration, February, 17, 2016.

${ }^{27}$ Interview with an official in Mi'esso of Oromia administration and Security office, Mi'esso, February, $17,2016$.

28 Interview with Oromo elder, Mi'esso, February, 16, 2016.

${ }^{29}$ Interview with police commander in Mi'esso of Oromia, February, 17, 2016.

${ }^{30}$ Currently the former Borana Region is divided into three administrative zones: The Borana and Gujii zones of the Oromia region and the Liban zone of the Somali region.

31 The Somali regional state divided the former Liban zone in to two and created new and named it Dawa zone.
} 
share both Oromo and Somali ethno-linguistic features, to identify themselves with either the Oromia or the Somali region. The process of inter-regional boundary making was thus intertwined with renegotiation of identity (Asnake, 2010: 621).

Along similar line, Teshome reasons that the Borana and Garri developed mutual suspicion after the Ethio-Somali War in 1977/78. One of the reasons was that the Garris were considered as the supporters of the Somali government during the war. Hence, when the war ended, some of the Garri members became refugees into Kenya and Somalia. After the overthrow of the Derg Regime in 1991, the Gerri returned to Ethiopia as returnees and settled in and around Moyale Woreda. Since 1992, both the Oromia and Somali regions have claimed the town and its surrounding areas and has become an area of flashpoint. The claims and counter claims resulted in the formation of double administration for one and the same town. This invited both regions' local administrations and local ethnic-based elites to get involved directly and indirectly which aggravated the conflict (Teshome, 2009).

Moreover, the large influx of Garri and other Somali 'returnees' to the town of Moyale and its surroundings through the controversial refugee repatriation programmes provided an additional incentive for the Garri to demand their inclusion in the Somali region (Bassi,1997; Getachew, 1996 cited in Asnake, 2010:621). For the Gabra, by contrast, deciding on the question of whether to join the Oromia or the Somali region proved internally divisive and brought those more conflicts with the Borana. The position of the Gabra is one of vacillation between the two regions (Asnake, 2010:621). Until 2018, the same episode of conflict continued to be manifested around Moyale.

\subsection{Territorial Claims and Conflict}

A long-standing resource and territorial disputes between the Borana on one side and the Garri and other Somali clans on the other turned into inter-regional boundary conflict between the Oromia and Somali regions in the post-1991 political context. The Garri lived under the Oromia administration, and the Garri ethnic entrepreneurs chose to join the Somali region immediately after its establishment in January 1993. Soon after that decision, they began laying claim to territories which were either jointly used by them and the Borana or belonged to Borana. These included two of the nine prominent Borana permanent water wells named El Ley and El Gof as well as Moyale town (Asnake, 2010:624).

By the same token, Teshome (2009) argues that during the transitional period, fighting started between the two groups. According to the Borana version of the story, the Garri, with the assistance of some government officials reoccupied areas like Ela Ley, Ela Gof, Dhoksu, Igal, Badde and the like and thereafter, the area under question were confined to Somali regional state. But the Garris argued that the land they settled on belongs to them. They claimed that they had been pushed away from that area during the Derg regime and that they had only repossessed their own land that they believed lost. The argument over the ownership of land between Gerri and Borana was not limited to grazing land but also dealt with land for watering and traditional gold mining, and furthermore the right to administer Moyale town (Teshome, 2009).

Asnake (2010), argues that the continued standoff over Moyale shows how inter-group relations have become entangled in the new politics of the Somali and the Oromia regions. The federal government has attempted to resolve the conflict through both political and legal instruments, but without success. The two regions still contest the ownership of Moyale town which lies on the Ethiopia-Kenya border and because of this unresolved territorial dispute, there are now dual and conflicting Somali and Oromo administrations within the town, including Oromo and Somali police stations, courts, public prosecutors' offices, finance and educational institutions, all with overlapping and competing jurisdictions. The town has been unofficially divided into two zones the eastern part of the town for the Garri and the western part for the Borana and the asphalt road that dissects the town serves as unofficial boundary (Asnake, 2010). Pertaining to this issue an informant from Moyale of Oromia enlightened that:

The causes of the conflict along the borders of Moyale Oromia and Moyale Somali are multiple. The first is that in the post 1991, the Garris are claiming the land area which originally belonged to the Borana. The second, is that the intention of the Garri is to control the areas of Moyale district including Moyale town through strategic illegal settlement and border expansion schemes. The third is that the absences of clear administrative boundary and the unresolved long standing and frequent conflicts between both communities. Fourthly, the scarcity of natural resources accompanied by environmental impacts has also detrimental effect on the conflict in the area. ${ }^{32}$

Likewise, another informant from Moyale Oromia stated that the context of the conflict has been changed around Moyale for the reason that when the Gerri came back from their refugee life in Somalia, they settled on the land which was formerly belonged to Borana. In addition, Borana has a tradition for receiving settlers to allow using grazing and watering on its land. However, the Gerri violated this long traditional practice first to contact the Aba Ela. The practice forced the settler first to contact the Abba Ela. Later on, the Abba Ela elders and the leaders of the area (Dida) would consult each other, and then allow a certain family to settle and share grazing land and water points. This traditional practice of the Borana was violated by the Gerri returnees and settled in the area without securing the permission of Abba Ela and erect their flag claiming that they have the right to settle and live in the area. ${ }^{33}$

This implies that the causes of the conflict in the area are supposed to be multiple. The grazing and watering points of the Borana were taken without the will of the Borana and thus they considered this as border expansion and the Borana felt that their traditional practices of receiving settlers was undermined. The Borana viewed these situations as the Garri had a dream and strategic plan to control and own economic and administrative power over the rural and urban areas of Moyale district. This would make the Borana community nervous and forced them to prepare themselves for frequent conflict. These areas are considered historic to Boranas" where both Kenyans and Ethiopian- Boranas had lived and still living, but

32 Interview with official in Moyale wereda, Moyale, September, 15, 2015.

33 Interview with Aba Gada in Moyale of Oromia, Moyale town, September, 15, 2015. 
with an anxiety and constant fear of recurrent conflict. On the other hand, the Somali informants counter argued the Borana narrative saying:

It is the nature of pastoral livelihoods that demand mobility guided by the need for access to water and grazing land rather than expansion for bordering lands. The cause of the conflict is about competition over resources. When this movement is restricted often it ends up with violent conflict with neighboring groups. The Garri's interests and what they seek to achieve in this conflict is to have access and use of all resources in the southern part of Ethiopia in equal foot with that of the Borana. ${ }^{34}$

In this regard, Gololcha (2015:61), states that the objective of Garris in the area was that of owning all the economic and the political benefits of Moyale town. Likewise, Melkamu (2016) noted that being closely linked with leadership of Somali region, the Garri were tasked to ensure the territorial autonomy of the land under their control and in some case to herald the redefinition of the boundary in areas which they suppose the Borana took over their land using historic advantages (Melkamu, 2016:49).

An official from Garri depicted that "the Borana still stick to their traditional and historical positions which grantees them upper hand in the area. In this regard, the Garri are forced to enter in to conflict to avert the status-quo to share the resource that Borana is usually claiming ownership and the Garri are also entitled to own the resource in the area." 35 Another informant also reported that "... Conflict memory continues to be a motivation for attacking, injuring and killing. Each community has memorized the incidence of violent attacks by their adversaries, and as a result the feelings of hatred have gradually been built up and passed over the decades to generations."

Moyale not only has two separate administrations, segregated schools, and parallel court systems but also rival police forces and confrontational local militia. More than 20 years after ethnic federalism was introduced, tensions between the two sides - Borana Oromo and Garri Somalis - were as fraught as ever. Gardner ${ }^{36}$ interviewed Ibrahim in Moyale

There is a serious problem emerging," said Ibrahim, an elderly Somali man in the courtyard of a hotel on the Oromo side of the road. As a clan elder, he has freedom to sit in places that younger Garri men would avoid, he said. Ill feeling between the two communities stretches back decades, but recent events have reopened old wounds. A clash between two armed groups near Moyale in April resulted in tit-for-tat killings, with at least one Garri and one Borana reported dead (both groups claim more), and injuries on either side (May, 16, 2017).

The data obtained from Oromia Administration and Security Bureau explains that each conflicting group from both areas were strengthening power by gathering gunmen, initiating others to cooperate with them, provoking each party to fight, equipping members with gun, hiding or accommodating criminals and creating alliances. Consequently, each group sought its own way of defending itself against the perceived menace or danger to come from other ethnic community. Such an action by one of the ethnic groups would become a kind of early warning" for a neighboring ethnic community which would feel that its security was being threatened (OBAS Archive, 2013). ${ }^{37}$

As discussed earlier, factors behind the Moyale conflict were several some of which were explicit while others were quite implicit and also largely diverse and multi-dimensional. One of the factors for conflict, according to some informants was related to the history of the "Greater Somalia" ambition leading to territorial claims. In 1970s the Somali forces guided by that ambition and attacked Moyale. In this regard, an official from Oromia regional state reported through media that in the conflict broke out around Moyale (Chamuk, Guchi, Lag sure and Wachile localities) in September 2017, a member of Somalia Republic National Army was captured with his ID Card while fighting on the side of the Somali regional state guided by the Garri against the Oromia regional state where the Borana were at the forefront. ${ }^{38}$ However, the Embassy of Somalia based in Addis Ababa, did not confirm this allegation. No matter whether the conflict was treated from the pastoralist dimension of resource competition or from the politics of ethnic federalism which required the assignment of territory to one ethnic group against the other territory was a crucial element. As a result, conflict over territory often combines strong economic and emotional values (USAID, 2012: 16).

Demarcating the boundary of the two regions around Moyale have become contentious because not only there were longstanding resource and territorial conflicts among the three groups but also due to the difficulty of dividing the three groups into clear-cut ethnic categories/regions (Melkamu, 2016). This implies that conflict over territory could express itself in the form of identity conflict so long as the members of identity groups have interest in articulating their claims through the lenses of ethnic identity. Elites can easily politicize ethnicity to access political or economic benefits. Based on this argument, one can easily understand that the conflicts in Moyale and its areas exhibits politicized ethnicity. On top of this, the other cause of conflict was that the area is the main route of contraband revenues which is the back bone of contention among the local elites. ${ }^{39}$ Over all, territoriality, politicization of ethnicity, socio-economic factors and environmental pressures emerged as critical factors in understanding the conflict dynamics around Moyale.

In general, the introduction of the federal structure along ethnic line without viable conflict prevention, EWER institution contributed in shaping the old pastoral resource competition to be politicized by elite and transformed in to territorial claims. Unfortunately, instead of improving, resource availability around borders has been worsened and resources governance became weakened. As a result, the current situation is distinct from the old ones for the reason that the conflicts are not merely about access to pasture and water points, it was rather about questions of ownership to territory.

\footnotetext{
34 Interview with Garri elder of Moyale (Somali), September, 15, 2015.

35 Interview with a Garri official in Moyale, September, 15, 2015.

36 Tom Gardner is the editor journalist of the Guardian Newspaper on issues of Governance; see the Guardian Newspaper, Tuesday, May 2017.

37 The researcher could not manage to get written document from Somali region to make comparison in this regard. However, the informant from the same region depicted the causes mentioned above are the main head ache of the region.

${ }^{38}$ Addisu Arega, Oromia Regional State Communication Bureau Head, Oromia Broadcast Network News 1:00 hr. 13 , Sept 2017

${ }^{39}$ Interview with Oromia (Moyale) official, 2016, Moyale Town, September, 20, 2015.
} 
Conflicts previously confined to rural and pastoral resource areas have also now spread to towns and politico-economic centers such as Mi'esso and Moyale towns. Moreover, this has also contributed to ethnic polarity as understood from the realities of the conflict of the HOA concerns, the "We" and "Those", "They" and "Us" and "Ours" and "Others" mentality deconstructed that had led to the loss of togetherness, empathy and sympathy among the peoples. This opened the way for political entrepreneurs and ethnic activists to fire the tensed groups to go to ethnic conflicts. In all incidents of conflicts between Oromia and Somali regional states, several reports on several occasions since 2011 were brought to the MOFPDA from regional states, zones, districts and local residents in several towns and villages along the borders but failed to end the conflict.

\subsubsection{The Idea of Greater Somalia as a Historical Factor}

States in the Horn of Africa are colonial creations. The post-independence Somali political scene was dominated by the vision to incorporate the Somali-inhabited regions in the Horn (Yasin, 2010:103). After Somalia became independent in 1960, the Republic Somalia set out to unite all Somalis in the Horn of Africa which had been delimited within three countries (Ethiopia, Djibouti and Kenya). This led to the foundation of the Somali nationalism around the idea of "' Greater Somalia', a 'political and symbolic construction aimed at establishing all- Somali inhabited territories of the North Eastern Africa into one Somali national state' ( Aguilar,1996:351 cited in Fekadu 2011:106).40 To realize this, the Siad Barre government supplied arms for liberation fighters in the adjoining areas of Ethiopia, particularly for Western Somali Liberation Front (WSLF), and for the Eritreans to get the support of Arab countries. Counteractively, Ethiopia, supported opponents of Siad Barre, known as Somali National Movement (SNM) and instigated clan rivalries to weaken the Somalia regime (Woodward, 1996).

This historical incidence of Somali nationalism and the Ethiopian response led to the Ethiopia- Somalia war of 1977/78. Ethiopia and Somalia have persuaded a competing concept of the territorial border: Ethiopia sought to maintain the colonial territorial border as defining the Ethiopian nation, while the Somali tried considered the same border that they considered as dividing the Somali nation and tried to remove it. The forceful implementation of these 'competing national missions' (Clapham 1996:241) led Ethiopia and Somalia to fight one of the bloodiest wars in the Horn of Africa. An influx of weapons to the area fueled the conflict between the communities along the common borders. In addition to the inflow of weapons in the area, there is a critic that such political mobilization has also had some influence on Ethiopian Somali ethnic groups. Some of the ex- soldiers of the ousted Said Barre regime immigrated to Ethiopia to the areas of Somali ethnic groups. They succeeded in influencing some Ethiopian Somalis to share their ambition of "Greater Somalia" (Alem Habtu, 2010: 165; Ewnetu, 2006).

The issues had direct impact on the territorial integrity of Ethiopia. According to promoters of the dream, the incorporation of western Somali (also called Somali Galbed) that refers to vast Somali, Oromo and Afar inhabited territory in eastern and southern Ethiopia was a crucial policy agenda. To this end, the Barre regime pursued the policy of dividing Ethiopians and tried to arm groups against the Imperial and Derg regimes (Asnake Menbere, 2013). The Greater Somali land dreamers, Yasin (2010:104) contends, claim large portions of Ethiopian regions of the South, Oromia, Harar, Dire Dawa and Afar stretching to Awash River where they planned to stop during the 1977 war. They considered all the mentioned territories within Ethiopia as the lost territories of the western parts of Great Somalia (ibid).

Citing oral sources collected from Oromo elders in Dire Dawa, Milkessa Midega wrote that:

Siad Barre government had claimed that its territory stretched to include Afar Region and Wollo areas in the northeast, Somali areas, Hararghe, Arsi, Bale, part of east Shewa including Adama from east to central Ethiopia, through Moyale to north Kenya in the south. To accomplish the so-called Greater Somalia agenda, he established military fronts in Ethiopia under five nomenclatures: Somali wariya aimed to control all Somali lands, Somali abo to incorporate Oromo areas, Somali ika for Afars, Somali ante for Wollo, and Somali enafde for Kenyans (Milkessa, 2013: 181).

Barre established these fronts as a mechanism to control eastern half of Ethiopia using Islam as an instrument. Actually, only Somali wariya and Somali abo successfully mobilized fighters and fought against the Imperial and the Derg regimes. The Oromos in Bale, Arsi and Hararghe were also keen to use the weapons from Siad Barre government to liberate Oromia from the Amhara-dominated Christian government of Ethiopia (ibid.). Religion was the underlying factor for the collusions in eastern Ethiopia. Milkessa observed instrumentality of religious identity for Siad Barre's political ends of creating Greater Somalia. Abdullah Salih, who was a soldier of Somali abo rebel force, witnessed this:

We joined Somali abo, under the leadership of an Oromo from Chercher, to topple down Ethiopia's Amhara government and liberate our land and people. We were provided military training and weapons in Mogadishu along with Somali wariya fighters [proper Siad Barre fighter] during which time both abo and wariya fighters vowed to be one people united by bloodIslam. [...]. Both Somali abo and Somali wariya conjointly fought the Amhara government in 1977 (interviewed in Milkessa, 2013: 181).

The territorial dispute that emerged between Ethiopia and Somalia since the 1960s, because of the aspiration of the latter to incorporate all territories mentioned above under its jurisdiction, adversely affected local inter-group relations in Ethiopia in the remaining years. In other words, the inter-state conflict instigated inter-group conflict, for example, in Moyale in southern Ethiopia where the Garri and the Borana supported Somalia and Ethiopia respectively to enter into local conflicts that continued to the present day. Between the late 1980s and early 1990s, the state collapse, famine, and the civil war in Somalia led to a reverse refugee flow from Somalia, including the Garri. By mid-1992, there were 594,000 refugees and 117,000 returnees

40 The idea of "Greater Somalia" was formulated in 1943 with the establishment of The Somali Youth League (SYL) on May 15, 1943 initially known as Somali Youth Club (SYC) which was aimed at struggling for the independence and unification of Somalia. This was symbolized in the national flag, which showed a five - pointed white star on a light blue background referring to the five territories under colonial rule (Drysdale, 1964). 
(Asnake, 2013:111). Some fled to refugee camps, others simply crossed the borders with or without their cattle, and tried to continue their lives in this new area. This process brought a new wave of Somali people to the region, and pushed the existing people further west into Borana territory (Helland, 1998 cited in Watson, 2001:10). Many of the returned pastoralists were heavily armed (Watson, 2001:10). As a result, the Garri and other Somali groups gained new control over territory and wells; and this control has since been consolidated, partly by the redrawing of the boundaries of the new administrative regions (Getachew, 1996; Bassi, 1997). As a result, the Borana, the Garri and other Somali clans have been fighting over these resources. Most of these fights have been concentrated in the areas where Oromia and Somali regions share borders today (Watson, 2001:10).

On the other hand, the Somali Regional officials argued for long time that the conflict bears no external factor associated with it, but only the common pastoralist day to day conflict in search of water and pasture. ${ }^{41}$ The key informant from this region depicted that “... the conflict between pastoralist communities along the borders of both regions has a long history, and it is basically on livelihood and competition over resources but it has nothing to do with the ambition of the greater Somalia." To the contrary, the data obtained from the archive of Oromia Regional Government, argue that the conflicts are attributed to the westward expansions by the Somalis which has an implicit agenda of promoting the 'Greater Somalia'. This has continued in its intensity and frequency in the last two decades. The recent instances of conflicts that have occurred in districts of East Hararge, West Hararge and Bale, Borana zonal administrations would prove the extension of the westward expansion and the proper image has been camouflaged under the disguise of the pastoralist society (Oromia Government Archive, 2017).

The legacies of the 1960s and 70s Somali politics in the Horn of Africa still has got impacts in the local level conflict between the Oromo and Somali. Some of the contested territories were included in the then irredentist claims by the Republic of Somalia. In southern Ethiopia, around Moyale, the patterns of conflicts we see today between Borana (Oromia) \& Garri (Somali) was set in the 1960s and 70s. In the 1990s there were suspicions that some of the ex- soldiers of Said Barre regime immigrated to Somali NRS of Ethiopia and instigate conflicts with old ideology. And some of the villages where conflicts take place are inhabited by returnees from Somalia after many years in Somalia refugee camps due to the 1960s and 70s conflicts. Therefore, the historical factors play out in the conflict as the perception and understanding of the actors is important.

\subsection{The Actors of the Conflict}

The researcher made reference of secondary sources and group discussions with Aba Gadas', clan leaders, local administrative officials at Mi'esso and Moyale of both regional states in 2016to identify actors of the Oromo - Somali border conflict in the pre and post 1991. Accordingly, the actors were various and complex mainly seen in view of state and non-state actors. They found from government structures up to the community levels and include ONLF, WSLF, and OLF forces. Regional political leaders are also participated in the conflict between the two regions as a neutral actor. The local leadership, militia, demobilized soldiers, Fetno-Derash of Oromia and the Liyu police of Somali were the major actors in the conflict. The Greater Somalia dreamers who were passionate from regional higher officers who took the regional position post 1992 are the conflicts of the conflict in the region. This has been confirmed by the former PM, Hailemariam, when he said:

Oromo and Somali communities were in border conflict from 1991-2018. Though the referendum was held in 2004 to resolve territorial claims, the conflict on the same continued with its destructive consequences. The problem of border conflict between Oromia and Somali Regional States is not a conflict between communities from both sides. The communities from either side do not enter in to a conflict. The conflict is between militias, Special Forces and leaderships of both regional states. It is the local leadership that is commanding the conflict [...]. (EBC, March, 16, 2017).

The forces have been fighting under the guise of local people, which has been strictly concealed at the administrative levels. Late in the post 1991, the Fetno-Derash of Oromia National Regional State is a para-military force primarily established to counteract the OLF which resumed guerilla warfare in different parts of Oromia including the Oromo - Somali border areas after it had withdrawn from the TGE.42 On the other hand, the Liyu (Special) Police of Somali National Regional State is a para military force has been established by the Somali government in 2008 to discharge security objectives in the Somali Regional State. These objectives were threefold: the containment of armed resistance by the ONLF and its Eritrean patrons; securing the porous border between Ethiopia and the Somali territories from enemy infiltration, notably by radical Islamic groups like al-Shabaab and, before that, by al-Ittihad al-Islamiyah and the United Western Somali Liberation Front (UWLSF); and influencing political developments in neighboring Somalia in line with Ethiopian interests (Hagmann,2014:29). A key point in the creation of Liyu Police was that Ethiopian authorities wanted to fight ONLF using the same clans as the ones that ONLF recruited from the Ogaden clans especially from the Abdille (Ali Yosuf) clan, the ex-president now under custody for human rights violation in the regional state. He has earned reputation for being a mercilessly anti-ONLF and for using cash and coercion to subdue, eliminate, or co-opt ONLF supporters by submitting them to important figures in the federal security apparatus (Hagmann, 2014:24). Thus, the Liyu police is often considered merely as a tool of repression in the hands of the federal government (International Crisis Group 2013: 12; Hagmann, 2014:32; Land info, 2016:6). The Liyu police has been accused of extrajudicial killings, kidnappings, and torture of dissidents in Somali regional state. In March 2012, Liyu police force massacred 19 peoples in two days (HRW, 2013). On the other hand, up until 2018, Liyu Police is not only responsible for fighting ONLF, but also for protecting the border and

41 This information was obtained from the introductory part of the report made by Oromia and Somali regional states' officials on issues of joint management of border conflicts, convened in Dire Dawa town, 2004.

42 Interview with ex-police commissioner of Oromia National Regional State, Addis Ababa, November, 20, 20016. 
for handling general security challenges in the region. Liyu Police has accomplished these tasks among other things by operating regional checkpoints and patrolling border areas. A number of media reports in 2015 showed that Liyu Police has been involved in battles and other incidents on the Somali side of the border of the Oromia Somali conflict. VOA News reported that the Liyu Police, based in SRS, have been accused of killing the Oromo ethnic group (VOA News, September 29, 2017 1:14 pm). The Oromo and Somali leaders accused each other of committing atrocities (Africa News, 09/10/2017).43

Sometimes later, this issue attracted the impetus of the highest law-making organ of Oromia National Regional State (ORNS) which reflected the matter on the "Caffee" Oromia meeting or Regional Council Meeting convened in Adama town. The discussion in the meeting, which was transmitted live on Oromia Television, was dominated by the issue of the conflict. Being nervous to the situation on the ground, members of the council openly spoke out that "the Oromia regional state was under attack by the Somali regional state Liyu Police at the forefront". The member of the regional council representing the border district from Eastern Hararge openly said:

... on the current ongoing conflicts, I am conveying to you a situation we are living in (communities around the border), we have been frustrated by the conflict, we experience daily. We have been attacked and invaded by the Somali Liyu Police backed by the Somali leadership at different levels. The scope of the conflict is beyond the competition for resources (watering and grazing points) but it is about territorial expansion. The Somalis are in war to ensure this expansion. In our eight districts most kebeles were invaded by this force and they (the Somalis) erected their flags. They are not satisfied in rural areas, now they are trying to invade the district capitals. We were denied services from our district offices. Public services such as Hospitals, schools were looted, destroyed.... When the Somali regional government was violently attacking us, the Federal army was watching. Why this army was not doing anything? [...] what has gone wrong in our relation with the Federal army? We have raised this issue before but the Federal government was pretending as if the issue was a conflict over water and pasture. In reality, it was not. It was rather a war for expansion of territory. The Federal force was reluctant to prevent such a conflict...In West Hararge, Mi'esso district, a member of the Liyu police have been captured and is in custody. 44

The open and emotionally charged discussions in the Caffee meeting implicates that the conflict has been transformed to territorial expansion. The Liyu Police has made attacks on the communities along the borders and revealed the political tension between the two ethno- national regional states and exposed the usually concealed actors in the conflict. In addition, not only the Liyu Police but also the Federal army has been implicated in the conflict through inaction which poses the question with regard to the intention of its neutrality. Overall, the members of the council also clearly articulated that the violent and deadly conflict taking place between the borders of both regional states was over territorial disputes pushed by the Liyu Police and backed by the Somali leadership.

\section{The Displacement Situation}

In the Oromo- Somali border conflicts have been built over a long period of time and brought about numerous economic, political and social (humanitarian) crisis mainly due to lack of viable institution of conflict prevention and early warning systems. The humanitarian situation has been further exacerbated by an upsurge in conflict around the border areas. While some IDPs were displaced frequently since the inception of the regionalization in the post 1991 by the conflict along the regional boundaries of both regional states, the vast majority of the displacements occurred from 2012 to 2018. After 2016 the conflict dynamics and displacement were changed since it was triggered by conflict between SomaliOromia over access to political power and regional boundaries.

$\mathrm{BBC}$ has also reported that some 70,000 people have fled their homes to a remote part of southern Ethiopia, after a deadly conflict broke out between Oromo and Somali clans. Since early September 2017 the conflict between Oromos and Somalis has left hundreds of thousands displaced people, and many more death and injury, often in areas already experiencing ongoing drought-related humanitarian need. Nearly all districts along the regional borders like Moyale, Meiso, Babile, Tulli-Guled, Mayu-muluko, Kubi, and Salahad were affected by this conflict.

Late, in September 2017, there was a clash in the Moyale district involving, in which more than 30,000 people crossed into Kenya to escape the fighting and dozens have been killed. On the other hand, According to OCHA, IOM and NDRMC at the end of October, around 60,000 Somali IDPs were believed to have been returned to their villages of origin in Moyale district and that most recent report also indicates IDPs in Guchi district (Borana zone, Oromia region) returned to their areas of origin. However, recurrent instability in these areas may not make their return sustainable

According to the National Disaster Risk Management Commission (NDRMC) estimate, around 857,000 people had been displaced by the Somali-Oromia conflict (this includes displacements recorded prior to August-September). Preliminary data 45 of the IOM Displacement conducted in November 2017 indicates that around 1 million persons have been displaced due to conflict along the Oromia-Somali regional border (nearly 700,000 in 2017 alone, with a significant spike after September 2017). The conflict IDP ${ }^{46} \mathrm{~s}$ are settled in close to 400 locations, either in IDP sites, with host communities or in "collective centers" along the border areas and in major towns or villages across Oromia, Somali, Harar regions, and Dire Dawa and Addis Ababa cities. Around 637,000 IDPs (60 per cent) are living in 145 spontaneous or planned camps/sites in the border areas. This includes 68,000 Somali IDPs - displaced between mid-2015 and end 2017 living in Qoloji IDP site located in Babile District (Babile Somali) on the Jijiga-Harar road [18]. ${ }^{47}$ Around 100,000 IDPs live

\footnotetext{
43 Available at http://www.africanews.com/2017/10/09/oromo-families-cry-foul-in-recent-conflict/accessed on September $13,2017$.

44 Taken from the speech of a member of Caffe Oromia on Ordinary Session of the Caffee Meeting, Adama, Galma Abagada Hall, and March, 2017.

${ }^{45}$ In October, the National Disaster and Risk Management Commission (NDRMC) proposed to use the IOM Displacement collected primary data that was conducted between November and December 2017 as the main information source to confirm IDP's locations and numbers.

${ }^{46}$ Internally Displaced People.

47 OCHA (2018). "Ethiopia: Conflict Displacement Situation Report”. For Public Circulation, January, 2018. Addis Ababa, Ethiopia.
} 
in government collective centers in Oromia regional state with most of the largest sites being located in major towns: Addis Ababa (2,500), Dire Dawa (4,700), Harar (4,500), Adama (3,100), and Chiro (4,700). Similarly, around 4,000 Somali IDPs are also located in a youth recreation center of Dire Dawa Administration. At least 256,000 IDPs live amongst host communities or relatives in the border areas or dispersed in the two regions, including around 5,000 Oromos displaced from Somaliland and dispersed in various locations in Oromia region. ${ }^{48}$

According to the Displacement Tracking Matrix (DTM) 1, at least 1,073,76449 People were displaced by conflict as of mid-April 2018. In May 2018, renewed violence between the Borana (Oromo) and Garre (Somali) communities living in Moyale has led to new internal displacement and protection concerns. According to a multi-agency assessment that visited the conflict-affected areas on 26 May, 15,645 households/ families (93,870 individuals) were displaced by this latest incident, including 3,702 IDP children. The most critical needs are lack of food, shelter, WaSH, health and nutrition services that require immediate interventions. In the meantime, the security situation in Moyale remains tense and unpredictable. In both regions IDPs remain in unsafe conditions both in their live and livelihood security, fully dependent on Government and international humanitarian assistance and generosity of the host community, which often times are themselves vulnerable due to recurrent drought impact.

Generally, the problem of the Somali-Oromia conflict was mainly motivated and influenced by these post-1991 political developments and changes that marked a turning point in the political history of the modern ethnic-based Ethiopian states.

\section{Conclusion}

Oromia and Somali regions share the longest border within Ethiopia. Although they share language, religion and culture, they have fought over the past 20 years. Clashes between both groups over border demarcations and natural resources have caused high numbers of casualties and deaths, as well as displacement. Multiple actors from local level to regional levels participated in the conflict in different capacities. From 2016 to 2018 the conflict escalates between SomaliOromia. Formerly, the Conflict is a resource-based conflict which was part of the livelihoods but after 2016 the situation has become more intricate due to politicization of the conflict and governance factors between both regional states. They pool to their own groups and exacerbate the conflict than addressing the causes and de-escalating the frequency of the skirmish. Thus, the new dilemma of conflict between Somali-Oromo ethnic groups also challenged the Ethiopian Government as the government lacks viable institution for conflict prevention, management and early warning systems to respond to inter-ethnic disputes.

Hence forth, both regional states are required to end longstanding tension and de-ethnicization and depoliticization of conflict related issues. More importantly both regional states need to strengthen horizontal and bi-lateral cooperation between them by initiating to establish peace and joint development institutions to deter the relapse of the conflict. In addition to this, they need to consult the traditional and religious leaders to guide the process of conflict resolution and bring the people together because they are the victims and major losers. Inter-regional cooperation is also required to promote reconciliation between the warring parties. By way of cultivating traditional mechanisms, community peace-building groups should be created that could develop into cross-border community peace building institutions. As stated by Hauss (2001), the clash of interests may not be compromised unless one of the parties gives up and/or steps back from specific demands that are antagonistic to the other. The Government of Ethiopia should create a common ground by which competing groups should come to terms by discussing their differences. Revealing the truth, indicting the guilty, building social capital, (because internal strife can obviously destroy social ties in the society), enhancing indigenous and traditional ways of conflict resolution mechanisms can help in bringing peace and stability in conflictridden areas. Finally, the government of Ethiopia and the regional states need to observe the Institutionalization of conflict prevention, management and early warning systems.

\section{References}

i. Abbink, J. (1997). "Ethnicity and Constitutionalism in Contemporary Ethiopia” in Journal of African Law, Vol. 41 No 2 Cambridge University Press, pp, 159 - 174.

ii. Abbink, J. (2011): Ethnic-based Federalism and Ethnicity in Ethiopia: Reassessing the experiment after 20 years, Journal of Eastern African Studies, 5:4, 596-618.

iii. Abeje Berhanu (2006). The Dizi and the Neighboring Surma: A case study of Interethnic Relations in Southwest Ethiopia, in Bekele Gutema, et al (eds.) Ethiopian Journal of the Social Sciences and Humanities, Vol. IV, N0. College of Social Sciences, Addis Ababa University, pp.1-12.

iv. Ahmed Mohamed and Fekadu Beyene, (2015) 'Social Capital and Pastoral Institutions in Conflict Management: Evidence from Ethiopia', Journal of International Development, Vol.28, Issue 1.

v. Ahmed Shide (2003) 'Conflict along Oromia -Somali Boundaries' A Paper Presented at the First National Conference on Federalism, Conflict and Peace Building. Addis Ababa, 5-7 May 2003.

vi. Albrecht Schnabel and David Carment, (2004) Conflict Prevention from Rhetoric to Reality: Organizations and Institutions. Volume 1(United Kingdom: Lexington Books 4.

vii. Alem Habtu (2010), 'Ethiopian Federalism, Principles, Processes and Practice, 5th International Conference on Federalism, Addis Ababa University Press. 
viii. Alem Habtu, (2003), 'Ethnic Federalism in Ethiopia: Background, Present Conditions and Future prospects', Paper Submitted to the Second EAF International Symposium on Contemporary Development Issues in Ethiopia, Queen's College/CUNY.

ix. Andreas Eshete (2003) 'Ethnic Federalism: New Frontiers in Ethiopian Politics' in First National Conference on Federalism, Conflict and Peacebuilding, PP. 142-71, Addis Ababa, MOFA and GTZ.

x. Asebe Regasa (2012) Emerging Ethnic Identities and Inter-Ethnic Conflict: The Guji-Burji Conflict in outh Ethiopia

xi. Asebe, Regassa (2012) 'Emerging Ethnic Identities and Inter-Ethnic Conflict: The Guji-Burji Conflict in South Ethiopia'

xii. Asnake Kafale, (2009) "Federalism and Ethnic Conflict in Ethiopia: A Comparative Study of the Somali and Benishangul-Gumuz Regions" (Leiden: University of Leiden, 2009).

xiii. Asnake Kefale (2004) 'Federalism: Some Trends of Ethnic Conflicts and their Management in Ethiopia', in A.G. Nhema (ed.) 'the Quest for Peace in Africa,' pp. 51-72. Utrecht: International Books.

xiv. Asnake Kefale (2011) "Federal Restructuring in Ethiopia: Renegotiating Identity and Borders along the OromoSomali Ethnic Frontiers." In Negotiating Statehood: Dynamics of Power and Domination in Africa, ed. T. Hagmann and D. Pe 'clard. Special issue, Development and Change 41 (2011): 615-35.

xv. Asnake Kefale, 2009; Federalism and ethnic conflict in Ethiopia: a comparative study of the Somali and Benishangul-Gumuz regions, Doctoral Thesis, Department of Political Science, Faculty of Social and Behavioural Sciences, Leiden University.

xvi. Asnake Menbere, 2013 "Resource" based Violent Conflict between Pastoralists of Ethiopia: An Exploration into Afar-Issa, Conflict InternationalJournalof Scientific Engineering and Research (IJSER) Volume 1 Issue 2.

xvii. Assefa Fiseha (2007) 'Federalism and Accommodation of Diversity in Ethiopia: A Comparative Study'; Nijmegen: Wolf Legal Publishers. 376-386.

xviii. Assefa Fiseha, (2006) Federalism and the Accommodation of Diversity in Ethiopia. Nijmegen: Wolf legal Publishers, pp. 379-380.

xix. Barth, F (1969), Ethnic groups and Boundaries, Little, Brown and Company, Boston.

xx. Burton, J. (1990). Conflict: Resolution and prevention. New York: St. Martin's Press.

xxi. Daniel Elazar, (1987) 'The Role of Federalism in Political Integration', in D. Elazar ed., Federalism and Political Integration (Ramat Gan: Turtledone Publisher, 1987), 20.

xxii. Davies, J.C. (1962). Toward a theory of revolution. American Sociological Review. 27 (1): 5-19.

xxiii. Dereje Feyisaa (2010) Conflict within the Ethiopian Federation a Reappraisal in Ethiopian Federalism: Principle, Process and Practice, Edited by Alem Habtu (5-243) Addis Ababa: 5th International Conference on Federalism Secretariat 2010. Addis Ababa University Press.

xxiv. Dereje Siyum, 2009; The Role of Local Governments in Conflict Management: The Case of Mieso Woreda, in An Anthology of Peace and Security Research, Vol. 3, Fredrich Ebert Stiftung, Addis Ababa, Ethiopia, P.72.

xxv. Federal Democratic Republic of Ethiopia (FDRE). "The Constitution of the Federal Democratic Republic of Ethiopia." Federal Negarit Gazeta 1, no. 1 (August 21, 1995). Published December 16, 1996.

xxvi. Fekadu Adugna, (2011), "Overlapping Nationalist Projects and Contested Spaces: The Case of the Oromo-Somali Borderlands in Southern Ethiopia." Journal of Eastern African Studies 5, no. 4: 773-87.

xxvii. Getachew Kassa. 2001a. Resource conflicts among the Afar of north-east Ethiopia. In: Salih MAM, Dietz T, Ahmed AGM, editors. African Pastoralism: Conflict, Institutions and Government. London, UK: Pluto Press, pp 145-171.

xxviii. Gurr, T. (1970). Why men rebel. Princeton, NJ: Princeton University Press.

xxix. Hagmann, T. and Alemmaya Mulugeta (2008). "Pastoral Conflicts and State-Building in the Ethiopian Lowlands." Africa Spectrum 43(1), pp. 19-37.

xxx. Hagmann, T; Mulugeta, A (2010) 'Pastoral Conflicts and State-building in the Ethiopian Lowlands'. University of Zurich.

xxxi. Hobbes, T. (1651), The Social Contract, A Treatise of Legal Philosophy and General Jurisprudence, Springer.com xxxii. Jeong, H. (2000) Peace and Conflict Studies: An Introduction (Aldershot: Ashgate).

xxxiii. Koestler, (1972), The Roots of Coincidence; Hutchinson \& Co Ltd.

xxxiv. Markakis J. (1994) "Ethnic Conflict and the State in the Horn of Africa”. In: Fukui K, Markakis J, editors. "Ethnicity and Conflict in the Horn of Africa". London, UK: James Currey, pp 217-237.

xxxv. Markakis J. (2003) "Anatomy of Conflict: Afar and Issa Ethiopia”, Review of African Political Economy, Vol. 30 Issue 97.

xxxvi. Markakis, J. (1998), "Resource Conflict in the Horn of Africa", International Peace Institute, Oslo Sage Publications Ltd,

xxxvii. Mohammud Abdulahi (2005) "The Changing Nature of Pastoral Conflicts in South-eastern Ethiopia: The Case of the Boran and Digodi Pastoralists." Africa Peace Forum, Pastoralist Concern Ethiopia, InterAfrica, Saferworld.

xxxviii. Muhabie, Kekkonen, (2015) "Ethnic Federalism: A Means for Managing or a Triggering Factor for Ethnic Conflicts in Ethiopia”, Social Sciences. Vol. 4, No. 4, 2015, pp. 94-105.

xxxix. Sandra Marker, (2003), Unmet Human Needs; Beyond intractability eds Guy Burgess and Heidi Burgess, Conflict Information Consortium, University of Colorado.

xl. Schlee and Shongolo, A. (1995). "Local War and Its Impact on Ethnic and Religious Identification in Southern Ethiopia" Geo Journal vol. 36, No. 1, Indigenous Peoples in Africa.

xli. Schelnberger (2005) "Decentralization" as a Means of Conflict Management a Case Study of Kibaale District", Uganda, Relhr University Bochum. 
xlii. Taddesse Berisso, (2009), "Changing Alliances of Guji-Oromo and their Neighbors: State Policies and Local Factors", in Günther Schlee and Elizabeth E. Watson ed. (2009), "Changing Identifications and Alliances in NorthEast Africa: Volume I: Ethiopia and Kenya", Berghahn Books.

xliii. Tadase and Yohanes (2016). "The impact of local conflict on regional stability in Ethiopia: The case of Afar region". Published by the Institute for Security Studies, Brooklyn Square, 0075, (Tshwane) Pretoria, South Africa.

xliv. Teshome Mekonnen (2003). 'Conflict Frontiers between Oromia and Somali the Case study of Moyale Woreda' a Paper presented at the First National Conference on Federalism, Conflict and Peace Building. Addis Ababa, 5-7 May 2003.

xlv. Yidneckachew A. (2012). Ethnic Conflict Management and Conflict Transformation: The Case of Derashe and Konso in Southern Nations, Nationalities and People's Region (SNNRR). An Anthology of Peace and Security Research, Vol. 3, Riendrich Ebert Stiftung, Addis Ababa, Ethiopia, P. 258.

xlvi. Young, John (1998) 'Regionalism and Democracy in Ethiopia', Third World Quarterly 19(2):192-204. 